\title{
Simple molecular diagnostic method for Fragile $X$ syndrome in Egyptian patients: Pilot study
}

\author{
Nagwa A. Meguid', Manal F. Ismail ${ }^{\bowtie}$, Rasha S. El-Mahdy ${ }^{1}$, Maged A. Barakat ${ }^{2}$ and Mostafa \\ K. El-Awady 3 \\ 1Department of Research on Children with Special Needs, National Research Centre, Cairo, Egypt; ${ }^{2}$ Department of Biochemistry, Faculty of Phar- \\ macy, Cairo, Egypt; ${ }^{3}$ Department of Microbial Biotechnology, National Research Centre, Cairo, Egypt
}

Background: Poor knowledge about Fragile $X$ syndrome (FXS) may be a major barrier to early diagnosis that could improve quality of life and prognosis especially in the developing countries. Aim: The aim of this study was to evaluate simple and reproducible method for premutation detection in females of fragile $X$ families for the first time in Egypt. Subjects and Methods: We have developed a rapid modified polymerase chain reaction (PCR)-based screening tool for expanded Fragile $\mathrm{X}$ mental retardation 1 (FMR1) alleles. This method utilizes betaine as additive to facilitate FMR 1 gene amplification. We screened fifty three males, thirty two first-degree females; twenty normal healthy controls in addition to six reference samples. Results: Simple PCR method showed 16 males with abnormal CGG repeats, where 10 of their mothers and four sisters had FMR 1 premutation. Consanguineous marriage was present in $66.6 \%$ percent of the studied families. Studying the correlation between genotype and clinical manifestations showed premature ovarian failure in $40 \%$ and learning disability in $50 \%$ of the studied female carriers. Conclusion: FXS has to be ruled out in families with consanguineous parents, before assuming that familial mental retardation is due to autosomal recessive gene defects. Early carrier detection may reduce the number of affected children. In conclusion, more studies are still needed of much larger sample size with known allele sizes in order to guarantee the accuracy of the method used.

Key words: Fragile X syndrome, Consanguinity, Carrier detection.

Received: 06 June, 2013; revised: 16 May, 2014; accepted: 09 June, 2014; available on-line: 16 June, 2014

\section{INTRODUCTION}

Fragile X syndrome (FXS) is a multigenerational disorder and its effects on families do not emanate only from the affected children, but also from parents and grandparents. There is an increasing evidence that defects of a single gene play a significant, previously underestimated, role in other complex disorders. Several homozygous deletions were recently described in autistic offspring of healthy consanguineous parents, strongly suggesting that autosomal recessive gene defects are important causes of autism, too (Morrow et al., 2008). The presence of autistic-like features, such as hand flapping, perseveration in behavior and language, avoidance of eye contact and touch, spurred further research on the relationship between FXS and autism. Fragile X mental retardation 1
(FMR 1) gene gives rise to a family of disorders when its non-coding CGG-repeat element is expanded to either the premutation range (55-200 CGG repeats) or the full mutation range ( $>200$ CGG repeats). Alleles that have 45-54 CGG repeats are labeled as the "gray zone" because instability in transmission to the next generation is common. The molecular basis of the syndrome is usually an expansion of a repetitive CGG triplet sequence located in the 5'-untranslated region (5'-UTR) of FMR1 gene (Brown et al., 1996). Rarely, FXS results from other molecular alterations (such as point mutations or deletions) within FMR1 gene. The CGG repeat element is polymorphic, varying from 6 to 44 repeats in the normal range, from 45 to 54 repeats in the gray zone, and from 55 to 200 repeats in the premutation range. For alleles below the gray zone, CGG repeat is generally stable in parent-to-offspring transmissions. However, CGG elements in the premutation range become increasingly unstable with increasing repeat number, and alleles exceeding 59 CGG repeats can expand to a full mutation in a single generation, almost exclusively by transmission from mother to son (Kallinen et al., 2000; Willemsen \& Oostra, 2000). The expansion of the number of repeats above a threshold of approximately 200 repeats, results in hypermethylation of FMR 1 promoter region and a lack of gene expression which fail to express FMRP protein, this allele is termed as full mutation. The premutation is relatively common in the general population, present in approximately 1 in 130 to 250 women and 1 in 250 to 810 males (Fernandez-Carvajal et al., 2009; Hagerman et al., 2008). The full mutation is less common at approximately 1 per 2,500 to 1 per 4,000 (Coffee et al., 2009). Mothers who bring their children into the clinic are usually without apparent clinical involvement cognitively, although anxiety and depression are common (Roberts et al., 2009). Prevalence of FXS within the mentally subnormal males was found to be $6.4 \%$ in Egypt (Meguid et al., 2007). This relatively high prevalence of FXS may be attributed to a decreased awareness of early detection and prediction of genetic disorders together with the increased percentage of consanguineous marriages among the Arabs. Variation in FMR1 CGG repeat size is a useful biomarker of various types of risk that could affect parents, as it defines differences between "healthy" and "affected" and between full mutation and premutation carriers.

e-mail: manalfouad1@yahoo.com

Abbreviations: ADHD, attention deficit hyperactivity disorder; dNT$\mathrm{Ps}$, deoxynucleotide triphosphates; DMSO, dimethyl sulfoxide; FMR 1 , fragile $X$ mental retardation 1 ; FXS, fragile $X$ syndrome; FXTAS, fragile $X$-associated tremor/ataxia syndrome; $I Q$, intelligence quotation; PCR, polymerase chain reaction; POF, premature ovarian failure; 5'-UTR, 5'-untranslated region 
At present, DNA analysis of CGG expansion is primarily performed using Southern blot analysis, which is able to detect alleles spanning the range from normal to large full mutation alleles. However, this method lacks the resolution to accurately sized alleles. An alternative approach, using polymerase chain reaction (PCR) of the region spanning CGG repeat, provides much greater resolution although it suffers from the difficulty of amplifying CGG repeats greater than 100 to 150 repeats, due to the high GC content of the sequence being amplified (Saluto et al., 2005). Because of the increasing clinical importance and high prevalence, the identification of the premutation carriers, which can be detected only by the direct molecular analysis, is very important (Toledano-Alhadef et al., 2001). In our study we worked on the detection of mutations by using an efficient and reliable PCR protocol which enables the amplification of normal and premutated alleles in the suspected cases and in females of the families with FXS in order to give effective proper genetic counseling.

\section{MATERIALS AND METHODS}

Subjects. Fifty three male patients were recruited from Children with Special Needs Clinic, at the National Research Centre. Inclusion criteria were mental subnormality, speech disorder and score of 16 or higher in Hagerman's checklist (Hagerman et al., 1991). The following examinations were done to suspected males: thorough medical and family history; three generation family pedigree construction; full clinical examination; comprehensive evaluation (neurological and psychometric) of mental, cognitive, and motor abilities with assessment of linguistic and social skills; intelligent quotation (IQ) testing using Stanford Binnet Test; Illinois Test for all suspected males. Cases were suspected and selected as FXS when fulfilling more than five of the following checklist's clinical criteria: mental retardation; hyperactivity; short attention span; tactilely defensiveness; hand-flapping; hand-biting; poor eye contact; perseverative speech; hyperextensible metacarpophalangeal joints; large or prominent ears; large testicles; Simian crease or Sydney line; and family history of mental retardation. Autism Diagnosis Intervention-Revised (ADI-R) which is a comprehensive interview that provides a thorough assessment of individuals suspected of having autism or other autism spectrum disorders where these individuals were ruled out. PCR was performed in selected cases depending on Hagerman's checklist.

Thirty two first degree females $(15$ mothers and 17 sisters) of positive FMR 1 mutated males were enrolled in the study. Control groups included 20 healthy normal subjects (13 males and 7 females), in addition to 6 references DNA samples which were supplied from College of American Pathologists (CAP) with known CGG repeat number. An informed written consent was obtained from all participants or their parents.

PCR amplification for FMR 1 Gene CGG repeats. Genomic DNA was isolated from 2 to $3 \mathrm{ml}$ peripheral blood using Axygen kit (Axygen bioscience, USA) according to the manufacturer protocol, DNA samples were stored at $-20^{\circ} \mathrm{C}$ till analysis. CGG repeat amplification method was used, originally as described by Saluto and coworkers (2005) and tested the effect of our different amplification conditions. Different additives including dimethyl sulfoxide (DMSO) and betaine were used. Betaine was used at concentra- tions of $1.5 \mathrm{M}, 2 \mathrm{M}$ and $2.2 \mathrm{M}$. Two enzyme mixes were used: Expand Long Template PCR Enzyme (Roche Diagnostics, Mannheim, Germany) and Long PCR Enzyme mix (Fermentas, Eu). For the first enzyme mix, the included three reaction buffers were tested as well. The optimized PCR reaction was applied on all control samples including the six reference samples, then on all 85 suspected samples.

The optimal PCR conditions were applied for all tested samples. It was as follows: $0.33 \mu \mathrm{mol} / \mathrm{L}$ from each primer, the $\mathrm{c}$ and $\mathrm{f}$ primers (5'agc ccc gca ctt cca cca cca gct cct cca-3', 5'-gct cag ctc cgt ttc ggt ttc act tcc ggt-'3) (Fu et al., 1991), PCR reactions were performed with the Expand Long Template PCR System (Roche Diagnostics), using buffer 2, $500 \mu \mathrm{mol} / \mathrm{L}$ dNTPs, 90-270 ng of genomic DNA. 2M betaine (B0300; Sigma-Aldrich, St. Louis, MO) in a final volume of $30 \mu \mathrm{l}$ and the cycling profile was as follows: denaturation at $98^{\circ} \mathrm{C}$ for 10 minutes; 10 cycles at $97^{\circ} \mathrm{C}$ for 35 seconds, $64^{\circ} \mathrm{C}$ for 35 seconds, $68^{\circ} \mathrm{C}$ for 4 minutes; 25 cycles at $97^{\circ} \mathrm{C}$ for 35 seconds, $64^{\circ} \mathrm{C}$ for 35 seconds, $68^{\circ} \mathrm{C}$ for 4 minutes, plus a 20 -second increment for each cycle; and a final extension at $68^{\circ} \mathrm{C}$ for 10 minutes. The expected constant region of the PCR product was $221 \mathrm{bp}$.

CGG repeats calculation. To calculate the CGG repeat, $5 \mu \mathrm{l}$ from each PCR product were electrophoresed at $6 \mathrm{~V} / \mathrm{cm}$ for 45 minutes on a $2.0 \%$ agarose gel in $1 \mathrm{X}$ TBE containing ethidium bromide. Snapshot of the gel was captured at the end of electrophoresis. Gene Tool software (Syngene, Cyprus) was used to calculate the base pair size of the unknown bands of PCR products; it draws a standard curve using the size and distance travelled by each band of the DNA
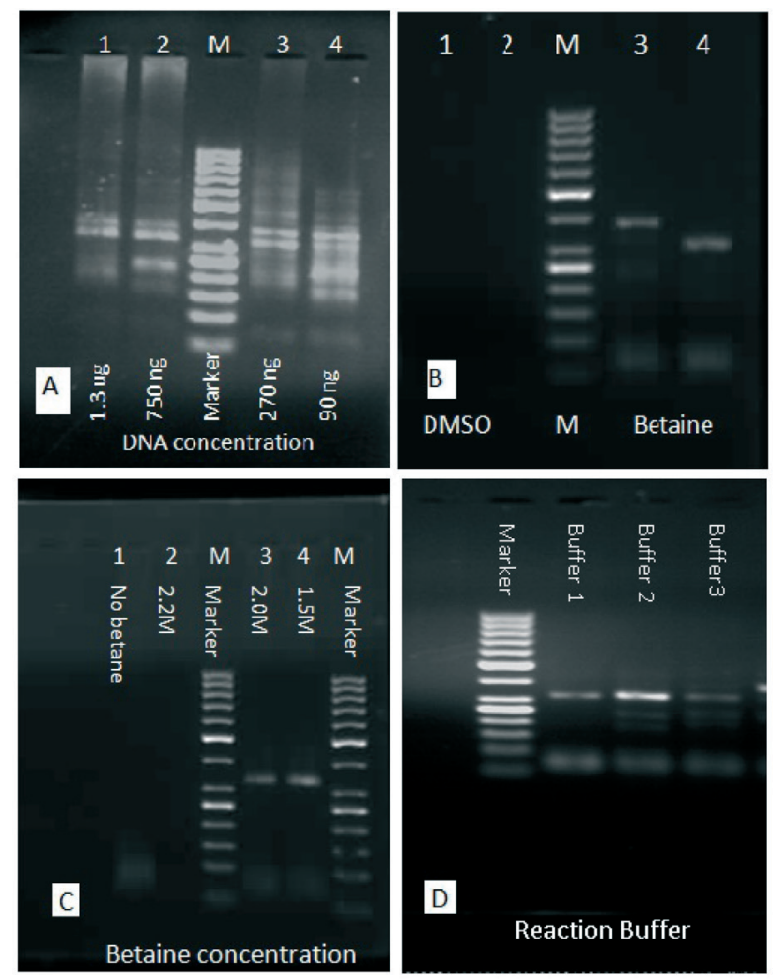

Figure 1. Optimization of FMR 1 gene Amplification.

Five microliters of PCR products were loaded per lane: (A) testing of DNA concentration; (B) testing of betaine and DMSO separately; (C) effect of betaine concentration; (D) testing of different reaction buffer supplied with expand long enzyme mix, and M, 50-bp DNA ladder molecular weight marker. 

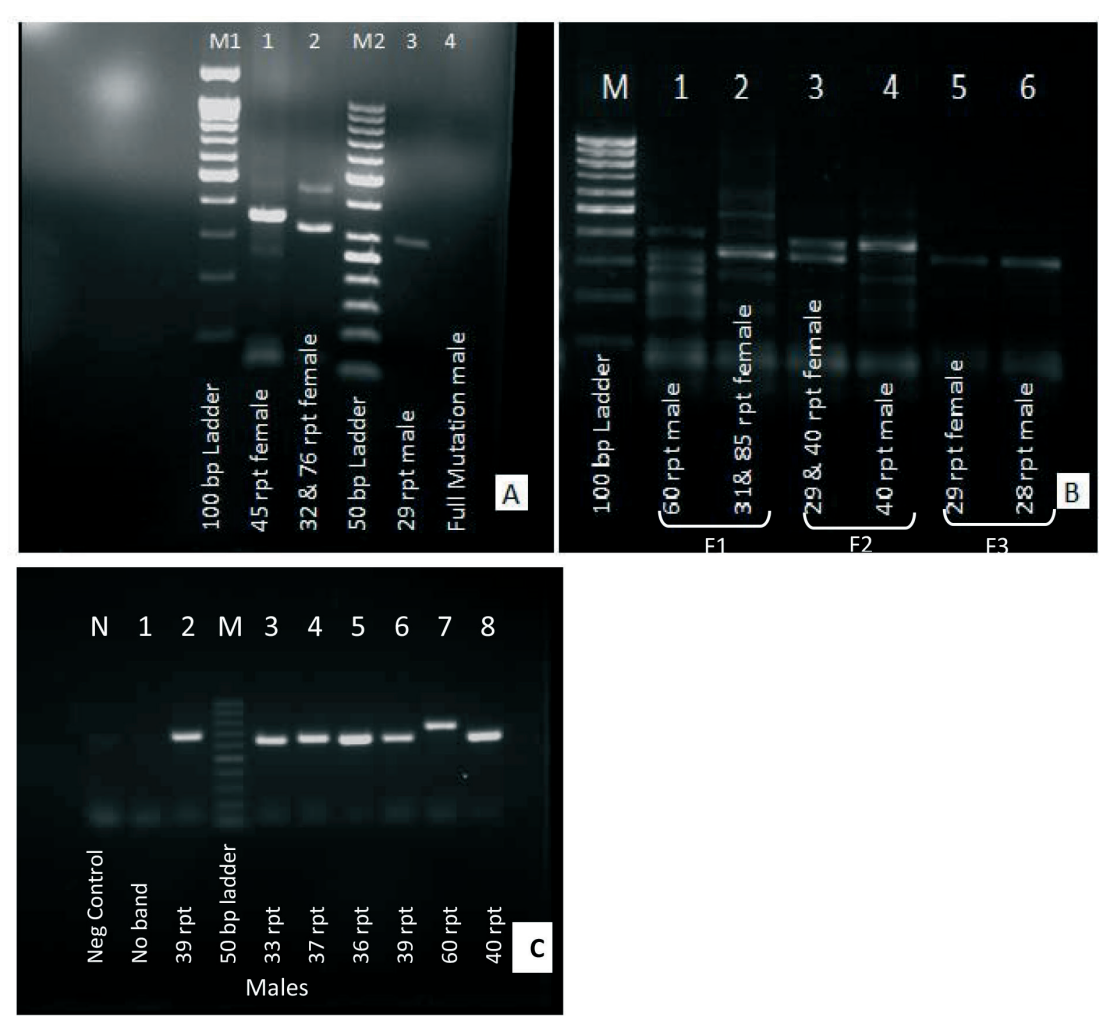

Figure 2. Application of the optimized PCR protocol on clinical samples.

Amplified PCR products were loaded into $2 \%$ agarose gel stained with ethidium bromide: (A) different males and females samples; (B) mothers and their sons; (C) male patients' samples with different pattern of mutation. M1, 100-bp ladder molecular weight marker. M2, 50-bp ladder molecular weight marker.

ladder, and then it uses this standard curve to calculate the size of each unknown band.

Agarose Detection of CGG Repeat ExpansionFMR1 CGG repeat region was amplified using the Expand Long Template kit (Roche Diagnostics); PCR products were visualized directly on agarose gel. To establish the optimal amplification conditions of FMR 1 CGG repeat region; PCR parameters were tested on three control samples, where different concentrations of genomic DNA (90 ng, $270 \mathrm{ng}, 750 \mathrm{ng}, 1.3$ $\mu \mathrm{g})$ with the three available buffers in the kit (buffers 1,2 , and 3), with and without different concentrations of betaine $(1.5,2.0,2.2 \mathrm{~mol} / \mathrm{L})$, also we tested DMSO with betaine, at concentrations of $1.5 \mathrm{M}$ or $2 \mathrm{M}$ in buffer $2(2.25 \mathrm{mmol} / \mathrm{L} \mathrm{MgCl})$ with $270 \mathrm{ng}$ of genomic DNA. There was a differential amplification in the two alleles based on the DNA concentrations: at low DNA concentration, band of higher CGG repeats was stronger than lower CGG repeats band and the opposite was true for high DNA concentrations. Moreover, we found that the optimal concentration of DNA that resulted in equal amplification of the two alleles was $270 \mathrm{ng}$. Using DMSO either alone or with betaine led to failure of the PCR amplification. The use of long PCR enzyme (Fermentas, Eu) provided same results obtained from the use of Expand long template (Roche) (Fig. 1). This assay detects normal and premutation but fail to detect fragile $\mathrm{X}$ full mutation. However, suspected males were selected according to the Hagerman check list and served as probands. We exclude DNA samples' males that gave normal bands; DNA samples' males that gave mutated bands (intermediate and premutation) or fail to amplify were included to facilitate selection of carrier females.

\section{RESULTS}

The obtained results regarding the six reference samples were concordant with the data provided from the CAP. Twenty healthy controls (13 male, 7 females) were also subjected to the same PCR conditions and showed a range of 29 to 36 CGG repeats. The present study detected 8 out of 53 $(15 \%)$ male patients with no bands, three $(5.6 \%)$ had premutation, five $(9.4 \%)$ fall in the gray zone and 37 had normal allele. Regarding thirty two female relatives (15 mothers, 17 sisters) of mutated males; 10 out of $15(66.6 \%)$ mothers were carrying FMR 1 premutation, and the allele of other 5 mothers $(33.3 \%)$ fall in a gray zone (Fig. 2). Besides, 4 out of 17 sisters also fall in a gray zone, and the rest were negative for fragile $\mathrm{X}$ analysis ( $\mathrm{Ta}-$ ble 1). First degree consanguinity was present in 10 families $(66.6 \%)$. Regarding clinical phenotype of females, premature ovarian failure (POF) was observed in 4 mothers out of $10(40 \%)$ with FMR 1 premutation. Learning disability was detected in 2 sisters out of 4 $(50 \%)$ whose alleles fall in a gray zone.

\section{DISCUSSION}

Although there is no current cure for FXS, the early and proper diagnosis has a great value to decrease the number of affected subjects with FXS by seeking early genetic counseling. Furthermore, the recent association of premutations with other medical disorders, such as Fragile X-associated tremor/ataxia syndrome (FXTAS) and POF emphasizes the importance of testing for FMR1 CGG triplet repeat expansions (Greco et al., 2006).

Traditionally, DNA analysis of the CGG expansion of FMR1 gene is primarily performed using Southern blot analysis, which allows an evaluation of both the expansion and the gene methylation status. PCR-based methods are also useful, especially for precisely sizing premutations or for excluding a diagnosis of fragile $\mathrm{X}$, when a normal CGG repeat allele is found in a male patient (Mandel \& Biancalana, 2004), but the main disadvantage of southern blot is expensive and inconvenient for rapid screening of large number of cases. Therefore, we aimed to validate an easy and robust methodology for detection of premutation carrier females of FXS and to distinguish between large normal and small premutation alleles which can't be detected by Southern blot. Several studies have described a number of PCR techniques, using diverse combinations of DNA polymerases, 7-deazadGTP, and co-solvents such as DMSO and betaine (Hecimovic et al., 2001; O’Connell et al., 2002; Todorov et al., 2010) to enhance amplification power and resolution. Most popular additives that have been used in this field are DMSO and betaine (Todorov et al., 2010; Saluto et al., 2005; O'Connell et al., 2002; Hecimovic et 
Table 1. Main Findings of the Studied cases

\begin{tabular}{|c|c|c|}
\hline Sex & CGG repeat size & Clinical phenotype \\
\hline $\begin{array}{l}\text { Male } \\
\text { Female } \\
\text { Female } \\
\text { Female } \\
\text { Male } \\
\text { Female } \\
\text { Female }\end{array}$ & $\begin{array}{l}\text { Not detected } \\
32,75 \text { CGG rpt } \\
32 \text { rpt } \\
33,81 \text { CGG rpt } \\
\text { Not detected } \\
33 \text { CGG rpt } \\
33 \text { CGG rpt }\end{array}$ & $\begin{array}{l}\text { Mental retardation } \\
\text { POF } \\
\text { Apparently Normal } \\
\text { POF } \\
\text { Mental retardation } \\
\text { Normal } \\
\text { Normal }\end{array}$ \\
\hline $\begin{array}{l}\text { Male } \\
\text { Female }\end{array}$ & $\begin{array}{l}\text { Not detected } \\
43,57 \text { CGG rpt }\end{array}$ & $\begin{array}{l}\text { Mental retardation } \\
\text { POF }\end{array}$ \\
\hline $\begin{array}{l}\text { Male } \\
\text { Female } \\
\text { Male } \\
\text { Female }\end{array}$ & $\begin{array}{l}\text { Not detected } \\
31,82 \text { CGG rpt } \\
\text { Not detected } \\
35 \text { CGG rpt }\end{array}$ & $\begin{array}{l}\text { Mental retardation } \\
\text { POF } \\
\text { Mental retardation } \\
\text { Normal }\end{array}$ \\
\hline $\begin{array}{l}\text { Male } \\
\text { Female } \\
\text { Female } \\
\text { Female }\end{array}$ & $\begin{array}{l}\text { Not detected } \\
29,93 \text { CGG rpt } \\
29 \text { CGG rpt } \\
29 \text { CGG rpt }\end{array}$ & $\begin{array}{l}\text { Mental retardation } \\
\text { Normal } \\
\text { Normal } \\
\text { Normal }\end{array}$ \\
\hline $\begin{array}{l}\text { Male } \\
\text { Female }\end{array}$ & $\begin{array}{l}\text { Not detected } \\
33,81 \text { CGG rpt }\end{array}$ & $\begin{array}{l}\text { Mental retardation } \\
\text { POF }\end{array}$ \\
\hline $\begin{array}{l}\text { Male } \\
\text { Female } \\
\text { Female }\end{array}$ & $\begin{array}{l}\text { Not detected } \\
33,65 \text { CGG rpt } \\
33 \text { CGG rpt }\end{array}$ & $\begin{array}{l}\text { Mental retardation } \\
\text { Normal } \\
\text { Normal }\end{array}$ \\
\hline $\begin{array}{l}\text { Male } \\
\text { Female }\end{array}$ & $\begin{array}{l}\text { Not detected } \\
35,59 C G G \text { rpt }\end{array}$ & $\begin{array}{l}\text { Mental retardation } \\
\text { Normal }\end{array}$ \\
\hline $\begin{array}{l}\text { Male } \\
\text { Female } \\
\text { Female }\end{array}$ & $\begin{array}{l}\text { Not detected } \\
33,56 \text { CGG rpt } \\
33 \text { CGG rpt }\end{array}$ & $\begin{array}{l}\text { Mental retardation } \\
\text { Normal } \\
\text { Normal }\end{array}$ \\
\hline $\begin{array}{l}\text { Male } \\
\text { Female } \\
\text { Female } \\
\text { Female } \\
\text { Female }\end{array}$ & $\begin{array}{l}\text { Not detected } \\
31,85 \text { CGG rpt } \\
33 \text { CGG rpt } \\
32 \text { CGG rpt } \\
36 \text { CGG rpt }\end{array}$ & $\begin{array}{l}\text { Learning disability } \\
\text { Normal } \\
\text { Normal } \\
\text { Normal } \\
\text { Normal }\end{array}$ \\
\hline $\begin{array}{l}\text { Male } \\
\text { Female }\end{array}$ & $\begin{array}{l}\text { Not detected } \\
44 \text { CGG rpt }\end{array}$ & $\begin{array}{l}\text { Mental retardation } \\
\text { Normal }\end{array}$ \\
\hline $\begin{array}{l}\text { Male } \\
\text { Female } \\
\text { Female }\end{array}$ & $\begin{array}{l}\text { Not detected } \\
45 \mathrm{CGG} \text { rpt } \\
44 \mathrm{CGG} \text { rpt }\end{array}$ & $\begin{array}{l}\text { Mental retardation } \\
\text { Learning disability } \\
\text { Learning disability }\end{array}$ \\
\hline $\begin{array}{l}\text { Male } \\
\text { Female } \\
\text { Female }\end{array}$ & $\begin{array}{l}\text { Not detected } \\
41 \text { CGG rpt } \\
39 \text { CGG rpt }\end{array}$ & $\begin{array}{l}\text { Mental retardation } \\
\text { Normal } \\
\text { Normal }\end{array}$ \\
\hline $\begin{array}{l}\text { Male } \\
\text { Female } \\
\text { Female } \\
\text { Female }\end{array}$ & $\begin{array}{l}\text { Not detected } \\
39 \text { CGG rpt } \\
40 \text { CGG rpt } \\
40 \text { CGG rpt }\end{array}$ & $\begin{array}{l}\text { Mental retardation } \\
\text { Normal } \\
\text { Normal } \\
\text { Normal }\end{array}$ \\
\hline
\end{tabular}

al., 2001). Other combined more than one additive at a time, Nolin and coworkers (2003) used 7-deaza-dGTP and betaine, whereas group from Turkey used 5\% of DMSO and 5\% glycerol (Bilgen et al., 2005).

In the current work, we evaluate the Expand Long Template PCR system (Roche Diagnostics, Mannheim, Germany) in conjunction with the use of betaine in accurately determining the size of large normal allele and small permutation allele. PCR products can be directly visualized on agarose gel after ethidium bromide staining and the number of repeats was correlated with the clinical outcome of suspected cases. We tested DMSO either alone or with betaine; the addition of DMSO to the reaction mix or the combination of DMSO and betaine led to a complete absence of the PCR product. On the contrary using betaine alone at concentration $1.5 \mathrm{M}$ and $2 \mathrm{M}$ gave the best results for the amplification of CGG repeats confirming the results obtained by Saluto et al., (2005). On the other hand, Tassone and her team found that the higher concentrations (2.2 M betaine) gave better results (Tassone et al., 2005). Several enzyme mixes and amplification kits have been developed in the past decades for meeting the demand for the amplification of long and complicated templates such as FMR 1 gene, we have tried the long PCR Enzyme Mix (Fermentas) in our study, despite being less expensive; it was as sensitive as the Expand Long Template PCR enzyme (Roche Diagnostics) which has been used by Saluto and coworkers (2005) and Tassone and coworkers (2005). As a pilot study, this simple inexpensive method may be used for screening and detection of premutation carriers.

Progressive neurological disorder in a portion of older premutation males (Tassone et al., 2000; Hagerman \& Hagerman, 2002) and findings of premature ovarian failure among premutation females raise additional issues for families and genetic counselors to consider (Sherman, 2000). Recently, great interest has been focused on premutation carrier detection, because premutation carriers have been reported to have increased prevalence of POF learning disabilities, attention deficit hyperactivity disorder (ADHD), intellectual disability and autistic features (Goodlin-Jones et al., 2004). POF has been observed in $\sim 21 \%$ of such carriers by the study of Sherman (2000). In the current study, POF was detected in 4 mothers out of $10(40 \%)$ with FMR 1 premutation.

It was reported that $C G G$ repeat alleles below the gray zone is generally stable in parent-to-offspring transmissions. In the present study, Gray zone alleles (45-54 CGG repeats) detected in mothers were stable in the next generation either transmitted to their sons or daughters, so mothers who have alleles in the gray zone should be reassured that the risk for having a child with FXS is extremely low. However, CGG repeats in the premutation range become increasingly unstable with increasing repeat number. Alleles exceeding 59 CGG repeats can expand to a full mutation in a single generation, almost exclusively by transmission from mother to son (Sherman, 2000; Murray et al., 2000). In the present work, we noticed a clear risk for expansion of premutation alleles to a full mutation in the next generation especially from mothers to sons and less frequently to their daughters.

Several studies had been conducted on premutation carriers to determine the smallest number of CGG repeats that can be expanded to full mutation in the next generation. Instability in the transmission of the gray zone alleles has been observed in $25 \%$ of alleles with $50-60$ repeats but in $<8 \%$ of those with $40-49$ repeats (Nolin et al., 1996). The risk of a full-mutation expansion in one generation from an allele of 55-59 repeats is 3.7\%-1.1\% (Nolin et al., 2003). Toledano-Alhadef and coworkers (2001) from Israel reported that there was no expansion of the premutation to the full mutation for alleles containing $<70$ repeats. Similar results were found by Ryynänen and coworkers (1999) and Pesso and coworkers (2000). Nolin and coworkers (2003) reported that smallest premutation allele number which can expand to full mutation in one generation in a different patient population was 59 repeats. In the present study, we reported that the smallest premutation allele number which can expand to full mutation in the next generation was 57 repeats.

Conclusively, this assay may be used as a screening method for premutation carriers with fragile X syndrome. Genetic testing is confirmatory of FMR 1 premutation and is an essential component of the clinical evaluation. Laboratory testing for fragile $\mathrm{X}$ mutations is highly reliable in both clinically affected patients and asymptomatic carriers. The identification of the full mutation can lead to the use of targeted treatments where 
new interventions are currently being studied in those with the premutation. Finally, we emphasized that recognition of a genetic disorder in a family has important implications for multiple members within the family tree. However, there is certain concern that this PCR fail to amplify full mutated and mosaic alleles.

\section{Conflict of interest}

Authors declared no conflict of interest.

\section{REFERENCES}

Bilgen T, Keser I, Mihci E, Haspolat S, Tacoy S, Luleci G (2005) Molecular analysis of fragile $\mathrm{X}$ syndrome in Antalya Province. Indian J Med Sci 59: 150-155.

Brown WT, Nolin S, Houck G Jr, Ding X, Glicksman A, Li SY, StarkHouck S, Brophy P, Duncan C, Dobkin C, Jenkins E (1996) Prenatal diagnosis and carrier screening for fragile X by PCR. Am J Med Genet 64: 191-195.

Coffee B, Keith K, Albizua I, Malone T, Mowrey J, Sherman SL, Warren ST (2009) Incidence of fragile X syndrome by newborn screening for methylated FMR1 DNA. Am J Hum Genet 85: 503-514.

Fernandez-Carvajal I, Walichiewicz P, Xiaosen X, Pan R, Hagerman PJ, Tassone F (2009) Screening for expanded alleles of the FMR 1 gene in blood spots from newborn males in a Spanish population. $J$ Mol. Diagn 11: 324-329.

Fu YH, Kuhl DP, Pizzuti A, Pieretti M, Sutcliffe JS, Richards S, Verkerk AJ, Holden JJ, Fenwick RG Jr, Warren ST (1991) Variation of the CGG repeat at the fragile $\mathrm{X}$ site results in genetic instability: resolution of the Sherman paradox. Cell 67: 1047-1058.

Goodlin-Jones BL, Tassone F, Gane LW, Hagerman RJ (2004) Autistic spectrum disorder and the fragile $\mathrm{X}$ premutation. $J$ Dev Behav Pediatr 25: 392-398.

Greco CM, Berman RF, Martin RM, Tassone F, Schwartz PH, Chang A, Trapp BD, Iwahashi C, Brunberg J, Grigsby J, Hessl D, Becker EJ, Papazian J, Leehey MA, Hagerman RJ, Hagerman PJ (2006) Neuropathology of fragile X-associated tremor/ataxia syndrome (FXTAS). Brain 129: 243-255.

Hagerman RJ, Amiri K, Cronister A (1991) Fragile X checklist. Am J Med Genet 38: 283-287.

Hagerman RJ, Hagerman PJ (2002) The fragile X premutation: into the phenotypic fold. Curr Opin Genet Dev 12: 278-283.

Hagerman RJ, Hall DA, Coffey S, Leehey M, Bourgeois J, Gould J, Zhang L, Seritan A, Berry-Kravis E, Olichney J, Miller JW, Fong AL, Carpenter R, Bodine C, Gane LW, Rainin E, Hagerman H, Hagerman PJ (2008) Treatment of fragile X-associated tremor ataxia syndrome (FXTAS) and related neurological problems. Clin Interv Aging 3: 251-262.

Hecimovic S, Vlasic J, Barisic L, Markovic D, Culic V, Pavelic K (2001) A simple and rapid analysis of triplet repeat diseases by expand long PCR. Clin Chem Lab Med 39: 1259-1262.

Kallinen J, Heinonen S, Mannermaa A, Ryynanen M (2000) Prenatal diagnosis of fragile $\mathrm{X}$ syndrome and the risk of expansion of a premutation. Clin Genet 58: 111-115.

Mandel JL, Biancalana V (2004) Fragile X mental retardation syndrome: from pathogenesis to diagnostic issues. Growth Horm IGF Res 14: S158-S165.
Meguid NA, Abdel-Raouf E R, Dardir A A, El-Awady MK (2007) Prevalence of fragile $\mathrm{X}$ syndrome among school-age Egyptian males. World J Pediatr 3: 271-275.

Morrow EM, Yoo SY, Flavell SW, Kim TK, Lin Y, Hill RS, Mukaddes NM, Balkhy S, Gascon G, Hashmi A, Al-Saad S, Ware J, Joseph RM, Greenblatt R, Gleason D, Ertelt JA, Apse KA, Bodell A, Partlow JN, Barry B, Yao H, Markianos K, Ferland RJ, Greenberg ME, Walsh CA (2008) Identifying autism loci and genes by tracing recent shared ancestry. Science 321: 218-223.

Murray A, Ennis S, Morton N (2000) No evidence for parent of origin influencing premature ovarian failure in fragile $\mathrm{X}$ premutation carriers. Am J Hum Genet 67: 253-254.

Nolin SL, Brown WT, Glicksman A, Houck GE Jr, Gargano AD, Sullivan A, Biancalana V, Bröndum-Nielsen $\mathrm{K}$, Hjalgrim $\mathrm{H}$, HolinskiFeder E, Kooy F, Longshore J, Macpherson J, Mandel JL, Matthijs G, Rousseau F, Steinbach P, Väisänen ML, von Koskull H, Sherman SL (2003) Expansion of the fragile X CGG repeat in females with premutation or intermediate alleles. Am J Hum Genet 72: 454 464.

Nolin SL, Lewis FA, 3rd, Ye LL, Houck GE, Jr., Glicksman AE, Limprasert P, Li SY, Zhong N, Ashley AE, Feingold E, Sherman SL, Brown WT (1996) Familial transmission of the FMR1 CGG repeat. Am J Hum Genet 59: 1252-1261.

O'Connell CD, Atha DH, Jakupciak JP, Amos JA, Richie K (2002) Standardization of PCR amplification for fragile X trinucleotide repeat measurements. Clin Genet 61: 13-20.

Pesso R, Berkenstadt M, Cuckle H, Gak E, Peleg L, Frydman M, Barkai G (2000) Screening for fragile X syndrome in women of reproductive age. Prenat Diagn 20: 611-614.

Roberts JE, Bailey DB Jr, Mankowski J, Ford A, Sideris J, Weisenfeld LA, Heath TM, Golden RN (2009) Mood and anxiety disorders in females with the FMR1 premutation. Am J Med Genet B Neuropsychiatr Genet 150: 130-139.

Ryynänen M, Heinonen S, Makkonen M, Kajanoja E, Mannermaa A, Pertti K (1999) Feasibility and acceptance of screening for fragile $\mathrm{X}$ mutations in low-risk pregnancies. Eur J Hum Genet 7: 212-216.

Saluto A, Brussino A, Tassone F, Arduino C, Cagnoli C, Pappi P, Hagerman P, Migone N, Brusco A (2005) An enhanced polymerase chain reaction assay to detect pre- and full mutation alleles of the fragile X mental retardation 1 gene. J Mol Diagn 7: 605-612.

Sherman SL (2000) Premature ovarian failure in the fragile X syndrome. Am J Med Genet 97: 189-194.

Tassone F, Hagerman RJ, Taylor AK, Gane LW, Godfrey TE, Hagerman PJ (2000) Elevated levels of FMR1 mRNA in carrier males: a new mechanism of involvement in the fragile-X syndrome. Am J Hum Genet 66: 6-15.

Tassone F, Pan R, Amiri K, Taylor AK, Hagerman PJ (2008) A rapid polymerase chain reaction-based screening method for identification of all expanded alleles of the fragile X (FMR 1) gene in newborn and high-risk populations. J Mol Diagn 10: 43-49.

Todorov T, Todorova A, Georgieva B, Mitev B (2010) A unified rapid PCR method for detection of normal and expanded trinucleotide alleles of CAG repeats in Huntigon chorea and CGG repeats in Fragile X syndrome. Mol Biotechnol 45: 150-154.

Toledano-Alhadef H, Basel-Vanagaite L, Magal N, Davidov B, Ehrlich S, Drasinover V, Taub E, Halpern GJ, Ginott N, Shohat M (2001) Fragile-X carrier screening and the prevalence of premutation and full-mutation carriers in Israel. Am J Hum Genet 69: 351-360.

Willemsen R, Oostra BA (2000) FMRP detection assay for the diagnosis of the fragile X syndrome. Am J Med Genet 97: 183-188. 